\title{
Zinc Inhibits Miniature GABAergic Currents by Allosteric Modulation of $\mathrm{GABA}_{\mathrm{A}}$ Receptor Gating
}

\author{
Andrea Barberis, ${ }^{1}$ Enrico Cherubini, ${ }^{1}$ and Jerzy W. Mozrzymas ${ }^{1,2}$ \\ ${ }^{1}$ Neuroscience Program and Istituto Nazionale Fisica della Materia Unit, International School for Advanced Studies (SISSA), \\ 34014 Trieste, Italy, and 2Department of Biophysics, Wroclaw University of Medicine, 50-368 Wroclaw, Poland
}

\begin{abstract}
Zinc is abundantly present in the CNS, and after nerve stimulation is thought to be released in sufficient quantity to modulate the synaptic transmission. Although it is known that this divalent cation inhibits the GABAergic synaptic currents, the underlying mechanisms were not fully elucidated. Here we report that zinc reduced the amplitude, slowed the rise time, and accelerated the decay of mIPSCs in cultured hippocampal neurons. The analysis of current responses to rapid GABA applications and model simulations indicated that these effects on mIPSCs are caused by zinc modulation of $\mathrm{GABA}_{\mathrm{A}}$ receptor gating. In particular, zinc slowed the onset of GABA-evoked currents by decreasing both the binding $\left(k_{\mathrm{on}}\right)$ and the transition rate from closed to open state $\left(\beta_{2}\right)$. Moreover, slower onset and recovery from desensitization as well as an increased unbinding rate $\left(k_{\text {off }}\right)$ were shown to underlie the accelerated deactivation kinetics in the presence of
\end{abstract}

Among all transition metals, zinc ions $\left(\mathrm{Zn}^{2+}\right)$ are particularly abundant in the brain, where they can be detected with the Timm's sulfide-silver staining technique (Timm, 1958). Using this method, large amounts of chelatable zinc have been localized in the cerebral cortex and in the limbic region (Frederickson, 1989). In the hippocampus, this divalent cation is stored in synaptic vesicles, present on mossy fiber terminals (Slomianka, 1992; but see, Lee et al., 2000), where it is colocalized with the putative zinc transporter ZnT-3 (Wenzel et al., 1997) and with the neurotransmitter glutamate. Stimulation of mossy fibers induces co-release of glutamate and zinc into the synaptic cleft (Vogt et al., 2000) where, according to the stimulation intensity, it can reach a local concentration up to $300 \mu \mathrm{M}$ (Assaf and Chung, 1984; Smart et al., 1994). It has been demonstrated that $\mathrm{Zn}^{2+}$ downregulates and upregulates NMDA and AMPA receptor-mediated responses, respectively (Peters at al. 1987; Westbrook and Mayer, 1987; Rassendren et al., 1990). Zinc has been also shown to inhibit GABA $_{\mathrm{A}}$ receptors (Westbrook and Mayer, 1987) (for review, see Smart et al., 1994). Although there is no evidence that zinc is co-released with GABA, it is likely that in the case of sustained nerve activation, $\mathrm{Zn}^{2+}$ spills over from glutamatergic terminals to neighboring GABAergic synapses, leading to inhibition of $\mathrm{GABA}_{\mathrm{A}}$ receptor-mediated responses (for review, see Smart et al., 1994). It should be stressed however that in this case the tonic concentration of $\mathrm{Zn}^{2+}$ will be much less than the peak local concentration at the release site. Several hypotheses have been put forward to explain inhibition of $\mathrm{GABA}_{\mathrm{A}}$ receptors by zinc. It has been proposed that zinc affects GABA-induced currents by reducing the frequency of channel opening (Legendre

\footnotetext{
Received June 12, 2000; revised Sept. 7, 2000; accepted Sept. 15, 2000.

This work was supported by a grant from Ministero dell'Università e Ricerca Scientifica e Tecnologica to E.C. J.W.M. was supported by Wroclaw University of Medicine Grant 561 and by Polish Committee for Scientific Research (KBN) research funds for Wroclaw University of Medicine, and A.B. was supported by a fellowship from Novartis Pharmaceuticals. The Bioq software with which the kinetic modeling was performed was kindly given by Dr. H. Parnas from the Hebrew University (Jerusalem).

Correspondence should be addressed to Enrico Cherubini, International School for Advanced Studies (SISSA), via Beirut 2-4, 34014 Trieste, Italy. E-mail: cher@sissa.it. Copyright (C) 2000 Society for Neuroscience $0270-6474 / 00 / 208618-10 \$ 15.00 / 0$
}

zinc. The nonequilibrium conditions of $\mathrm{GABA}_{\mathrm{A}}$ receptor activation were found to strongly affect zinc modulation of this receptor. In particular, an extremely fast clearance of synaptic GABA is implicated to be responsible for a stronger zinc effect on mIPSCs than on current responses to exogenous GABA. Finally, the analysis of currents evoked by GABA coapplied with zinc indicated that the interaction between zinc and $\mathrm{GABA}_{A}$ receptors was too slow to explain zinc effects in terms of competitive antagonism. In conclusion, our results provide evidence that inhibition of mIPSCs by zinc is attributable to the allosteric modulation of $\mathrm{GABA}_{A}$ receptor gating.

Key words: mIPSCs; GABA $A_{A}$ receptors; $\beta$-alanine; fast perfusion; nonequilibrium conditions; kinetics analysis; hippocampus; cell cultures and Westbrook, 1991), an effect that could be achieved either by a decreased or by an increased rate constant of GABA binding or unbinding, respectively. However, these possibilities have been considered unlikely because of the lack of effects of zinc on $\mathrm{GABA}_{\mathrm{A}} \mathrm{R}$ single-channel kinetics (Legendre and Westbrook, 1991; Smart, 1992; Smart et al., 1994). The possibility that binding of $\mathrm{Zn}^{2+}$ might allosterically trigger a transition to a long-lived nonconducting state has been suggested (Celentano et al., 1991; Smart, 1992; Smart et al., 1994; Gingrich and Burkat, 1998), but the mechanism of such modulatory effect has not been fully clarified. Alternatively, $\mathrm{Zn}^{2+}$ could increase the onset of desensitization, a phenomenon that may be responsible for the acceleration of GABA-induced current deactivation (Berger et al., 1998). This mechanism however, does not accord with Jones and Westbrook's (1995) finding that desensitization prolongs the deactivation process. It seems thus that the mechanism through which $\mathrm{Zn}^{2+}$ affects $\mathrm{GABA}_{\mathrm{A}}$ receptors remains uncertain. In particular, it is not clear whether a direct block of the channel pore is involved and to what extent $\mathrm{Zn}^{2+}$ inhibitory action is a consequence of an allosteric modulation of $\mathrm{GABA}_{\mathrm{A}}$ receptor kinetics.

The aim of the present work was to determine the mechanisms whereby zinc affects miniature IPSCs (mIPSCs) in cultured rat hippocampal neurons. We provide evidence that inhibition of mIPSCs by $\mathrm{Zn}^{2+}$ is caused by allosteric modulation of $\mathrm{GABA}_{\mathrm{A}}$ receptor microscopic gating, including binding, desensitization, and conformational change from bound closed to bound open state.

\section{MATERIALS AND METHODS}

Cell culture. Primary cell culture was prepared as previously described (Andjus et al., 1997). Briefly, postnatal day 2 (P2)-P4 Wistar rats were decapitated after being anesthetized with an intraperitoneal injection of urethane $(2 \mathrm{gm} / \mathrm{kg})$. This procedure is in accordance with the regulation of the Italian Animal Welfare Act and was approved by the local authority veterinary service. Hippocampi were dissected free, sliced, and digested with trypsin, mechanically triturated, centrifuged twice at $40 \times g$, plated in the Petri dishes, and cultured for up to $14 \mathrm{~d}$. Experiments were performed on cells cultured for at least $7 \mathrm{~d}$.

Electrophysiological recordings. Currents were recorded in the whole-cell and outside-out configurations of the patch-clamp technique using the 
EPC-7 amplifier (List Medical, Darmstadt, Germany). In the case of whole-cell recordings, the series resistance $\left(R_{\mathrm{s}}\right)$ was in the range of 4-8 $\mathrm{M} \Omega$, and $50-70 \%$ of $R_{\mathrm{s}}$ compensation was accomplished. Both mIPSCs and GABA-elicited currents in the excised patch configuration were recorded at a holding potential $\left(V_{\mathrm{h}}\right)$ of $-70 \mathrm{mV}$. The intrapipette solution contained (in mM): $\mathrm{CsCl} 137, \mathrm{CaCl}_{2} 1, \mathrm{MgCl}_{2}$ 2, 1,2-bis(2aminophenoxy)ethane- $N, N, N^{\prime}$-tetra-acetic acid (BAPTA) 11, ATP 2, and HEPES 10, pH 7.2 with $\mathrm{CsOH}$. The composition of the external solution was (in mM): $\mathrm{NaCl} 137, \mathrm{KCl} 5, \mathrm{CaCl}_{2} 2, \mathrm{MgCl}_{2} 1$, glucose 20, and HEPES 10 , pH 7.4 with $\mathrm{NaOH}$. mIPSCs were recorded in the presence of tetrodotoxin (TTX; $1 \mu \mathrm{M})$ and kynurenic acid $(1 \mathrm{~mm})$ to block fast sodium spikes and glutamatergic excitatory postsynaptic events. All the experiments were performed at room temperature $\left(22-24^{\circ} \mathrm{C}\right)$.

The current signals were stored on a video recorder following pulsecode modulation. For the analysis requiring a high temporal resolution (e.g., rise time kinetics of synaptic or evoked currents), the signals were low-pass filtered at $10 \mathrm{kHz}$ with a Butterworth filter and sampled at 50-100 $\mathrm{kHz}$ using the analog-to-digital converter CED 1401 (Cambridge Electronic Design, Cambridge, UK) and stored on the computer hard disk. The data and acquisition software were kindly given by Dr. J. Dempster (Strathclyde University, Glasgow, UK).

GABA, $\beta$-alanine, and zinc were applied to excised patches using an ultrafast perfusion system based on piezoelectric driven theta-glass application pipette (Jonas, 1995). The piezoelectric translator was from Physik Instrumente (Waldbronn, Germany), and theta glass tubing was from Hilgenberg (Malsfeld, Germany). In the case of high concentration (30 $\mathrm{mM}$ ) of GABA, the osmolarity was compensated by omitting glucose; in the case of high concentration (100 mM) of $\beta$-alanine, glucose was not added, and $\mathrm{NaCl}$ was reduced from 137 to $100 \mathrm{~mm}$. The concentration of chloride was still saturating the GABA receptor channels. The $[\mathrm{Cl}]$ in the pipette was adjusted to maintain the chloride solution symmetrical. The open tip recordings of the liquid junction potentials revealed that the 10-90\% exchange of solution occurred within $40-80 \mu \mathrm{sec}$. The speed of the solution exchange was also estimated around the excised patch by the $10-90 \%$ onset of the membrane depolarization induced by application of high $(25 \mathrm{mM})$ potassium saline. In this case the $10-90 \%$ rise time value $(60-90 \mu \mathrm{sec})$ was very close to that found for the open tip recordings.

In experiments aiming to study $\mathrm{Zn}^{2+}$ effects on $\mathrm{GABA}_{\mathrm{A}} \mathrm{Rs}$, GABA was applied in the presence of $\mathrm{Zn}^{2+}$ after pre-equilibrating the receptors with the same $\mathrm{Zn}^{2+}$ concentration for at least 1 min. In some experiments, GABA and $\mathrm{Zn}^{2+}$ were coapplied without pre-equilibration of $\mathrm{GABA}_{\mathrm{A}}$ receptors in $\mathrm{Zn}^{2+}$.

Data analysis. Synaptic currents were analyzed with the AxoGraph 3.5.5 program (Axon Instruments, Foster City, CA). This program uses a detection algorithm based on a sliding template. The template did not induce any bias in the sampling of events because it was moved along the data trace one point at a time and was optimally scaled to fit the data at each position. The detection criterion was calculated from the template scaling factor and from how closely the scaled template fitted the data. The threshold for detection was set at 3.5 times the SD of the baseline noise. Using the same program, the decay time constant of averaged mIPSCs was taken from biexponential fit of the decay time. The rise time was estimated as the time needed for $10-90 \%$ increase of the peak current response.

The decaying phase of the GABA-evoked currents was fitted with a biexponential function in the form:

$$
y(t)=A_{\text {fast }} \exp \left(-t / \tau_{\text {fast }}\right)+A_{\text {slow }} \exp \left(-t / \tau_{\text {slow }}\right),
$$

where $A_{\text {fast }}, A_{\text {slow }}$ are the fraction of the fast and slow component, respectively, and $\tau_{\text {fast }}$ and $\tau_{\text {slow }}$ are the fast and the slow time constants. In the case of analysis of normalized currents, the fractions of kinetic components fulfilled the normalization condition: $A_{\text {fast }}+A_{\text {slow }}=1$. In the case of current responses elicited by long duration GABA pulses $(\geq 50 \mathrm{msec})$, the desensitization onset was described by

$$
y(t)=A_{\text {fast }} \exp \left(-t / \tau_{\text {fast }}\right)+A_{\text {slow }} \exp \left(-t / \tau_{\text {slow }}\right)+A_{\mathrm{s}},
$$

where $A_{\mathrm{s}}$ is the steady state current.

Charge transfer $(Q)$ associated with GABA-induced current, was calculated as the current integral:

$$
Q=\int_{0} i(t) d t
$$

where $i(t)$ is the current and $t$, time. In the case of mIPSCs, the charge transfer was calculated by integration of the averaged trace.

Brief (1-2 msec) paired pulses separated by a variable time interval were used to test whether or not the entrance of bound receptors into the desensitized state proceeded after the agonist removal. The parameter $R$ was calculated according to the formula:

$$
R=\left(I_{2}-I_{\text {end }}\right) /\left(I_{1}-I_{\text {end }}\right),
$$

where $I_{1}$ is the first peak amplitude, $I_{\text {end }}$ is the current value immediately before the application of the second pulse, and $I_{2}$ is the second peak amplitude. During 1-2 msec pulse the onset of the use-dependent desensitization is minimal. Thus, in the case of continued entrance into the desensitized state after the first short agonist pulse, the peak of the second response $\left(I_{2}\right)$ was smaller than the first one resulting in $R<1$.

To determine the recovery from desensitization, the time duration of the first (conditioning) pulse was set sufficiently long to induce the usedependent desensitization, and the second (test) pulse was applied at variable time interval. The extent of recovery was assessed using Eq. 4, but $I_{\text {end }}$ in this case corresponded to the value of the current at the end of the conditioning pulse and $I_{1}, I_{2}$ represented the current peaks evoked by conditioning and test pulses, respectively. For the reasons explained in detail in Results, the recovery from desensitization was determined using this protocol only in the case of $\beta$-alanine.

The kinetic modeling was performed with the Bioq software kindly provided by Dr. H. Parnas from the Hebrew University (Jerusalem). The Bioq software converted the kinetic model (see Fig. 7) into a set of differential equations and solved them numerically assuming, as the initial condition, that at $t=0$, no bound or open receptors were present. Various experimental protocols were investigated by "clamping" the agonist concentration time course in the form of square-like pulses (ultrafast perfusion experiments) or of an exponentially decaying function (to model the synaptic clearance). The solution of such equations yielded the time courses of probabilities of all the states assumed in the model. The fit to the experimental data was performed by optimizing the values of rate constants. The procedure for the rate constants optimization was based on the comparison of the time course of recorded currents and that of simulated responses. As described in detail in Results, specific experimental protocols were used to estimate different sets of rate constants.

Data are expressed as mean \pm SEM, and all the values included in the statistics represent recordings from separate cells. Statistical comparisons were made with the use of unpaired $t$ test and Wilcoxon signed rank test ( $p<0.05$ was taken as significant).

\section{RESULTS}

\section{$\mathrm{Zn}^{2+}$ affects the kinetics of mIPSCs}

mIPSCs were recorded from cultured hippocampal neurons in the whole-cell configuration of the patch-clamp technique at a holding potential of $-70 \mathrm{mV}$ and in the presence of TTX $(1 \mu \mathrm{M})$ and kynurenic acid (1 $\mathrm{mm})$ to block fast sodium spikes and ionotropic glutamatergic currents, respectively. mIPSCs were $\mathrm{GABA}_{\mathrm{A}}$ mediated because they were reversibly blocked by bicuculline ( 30 $\mu \mathrm{M}$; data not shown). mIPSCs had a mean amplitude and frequency of $77.6 \pm 11.1 \mathrm{pA}$ and $3.1 \pm 0.4 \mathrm{~Hz}$, respectively $(n=11)$. $\mathrm{Zn}^{2+}(30-300 \mu \mathrm{M})$ reversibly reduced the amplitude of mIPSCs and shifted to the left the cumulative amplitude distribution in a concentration-dependent manner (Fig. $1 A, D$ ). The mean mIPSC amplitude reduction induced by $\mathrm{Zn}^{2+}(100 \mu \mathrm{M})$ was $65 \pm 5 \%, n=$ 5. $\mathrm{Zn}^{2+}$ at concentrations of 30-100 $\mu \mathrm{M}$ did not significantly $(p>$ 0.5 ) alter the frequency of mIPSCs (the mean frequency reduction was $15 \pm 13 \%$ and $20 \pm 19 \%$ in 30 and $100 \mu \mathrm{M} \mathrm{Zn}^{2+}$, respectively; see also DeFazio and Hablitz, 1998). At higher $(300 \mu \mathrm{M}) \mathrm{Zn}^{2+}$ concentration a significant $(p<0.001)$ reduction of $56 \pm 9 \%$ was detected. As suggested by the experiments with exogenous application of GABA (see next paragraph), in $\mathrm{Zn}^{2+}(300 \mu \mathrm{M})$, the extent of $\mathrm{GABA}_{\mathrm{A}}$ receptor inhibition would be so high that a considerable proportion of mIPSCs would fall into an undetectable level. This would lead to a decrease in apparent mIPSCs frequency, thus precluding a proper determination of averaged amplitude and charge transfer values (data not shown in Fig. 1).

The effect of $\mathrm{Zn}^{2+}$ on mIPSC amplitude was accompanied by a concentration-dependent decrease in the onset rate and acceleration of the deactivation kinetics (Fig. 1B,C,E,G). The 10-90\% mIPSC rise time increased from $0.68 \pm 0.03 \mathrm{msec}$ in control conditions to $0.91 \pm 0.02 \mathrm{msec}$ in $\mathrm{Zn}^{2+}(100 \mu \mathrm{M} ; n=11$; Fig. $1 G)$. In the absence of $\mathrm{Zn}^{2+}$, mIPSC decay was fitted with two exponentials characterized by $\tau_{\text {fast }}$ and $\tau_{\text {slow }}$ of $4.7 \pm 0.7 \mathrm{msec}$ and $33.7 \pm 3.1 \mathrm{msec}(n=10$; see also Edwards et al., 1990; Jones and Westbrook, 1995; Mozrzymas et al., 1999). In the presence of $\mathrm{Zn}^{2+}$ a clear acceleration of the decay was observed because of a decrease in the area and in the time constant of the slower component (Table 1). To assess the net $\mathrm{Zn}^{2+}$ effect on mIPSCs, the total charge transfer for different $\mathrm{Zn}^{2+}$ doses was calculated by integrating mIPSCs area. Thus, the total charge transfer was significantly $(p<0.001)$ reduced from $1759.5 \pm 248.6 \mathrm{nC}(n=10)$ in control to $369.5 \pm 79.6 \mathrm{nC}(n=6$; Fig. $1 F)$ in $\mathrm{Zn}^{2+}(100 \mu \mathrm{M})$. 
A

Figure 1. Concentration-dependent effect of $\mathrm{Zn}^{2+}$ on amplitude of mIPSCs and kinetics. A, Average of $64 \mathrm{mIPSCs}$ in control conditions and in the presence of $\mathrm{Zn}^{2+}(100 \mu \mathrm{M}) . B$, The two traces shown in $A$ are normalized and superimposed (thick line, control; thin line, $\mathrm{Zn}^{2+}$ ). C, Normalized mIPSC onset in control conditions and in the presence of $\mathrm{Zn}^{2+}(100$ $\mu \mathrm{M})$. Each trace is the average of $64 \mathrm{mIP}$ SCs. D, Cumulative amplitude histograms of mIPSCs in control conditions (thick line) and in the presence of $\mathrm{Zn}^{2+}$ $(100 \mu \mathrm{M}$, thin line). $E$, Cumulative rise time histograms of mIPSCs in control conditions and in the presence of $\mathrm{Zn}^{2+}$ (100 and $300 \mu \mathrm{M}$, respectively). $F$, Dosedependent effect of $\mathrm{Zn}^{2+}$ on mIPSC amplitude (gray columns) and on total charge transfer (white columns). Amplitudes and total charge transfers were normalized to control values. In this and the following figures, error bars indicate SEM. $G$, Each column represents the mean $(n=6-10) 10-90 \%$ mIPSC rise time value obtained in control (black) and in the presence of different $\mathrm{Zn}^{2+}$ concentrations (white).

$\mathrm{F}$
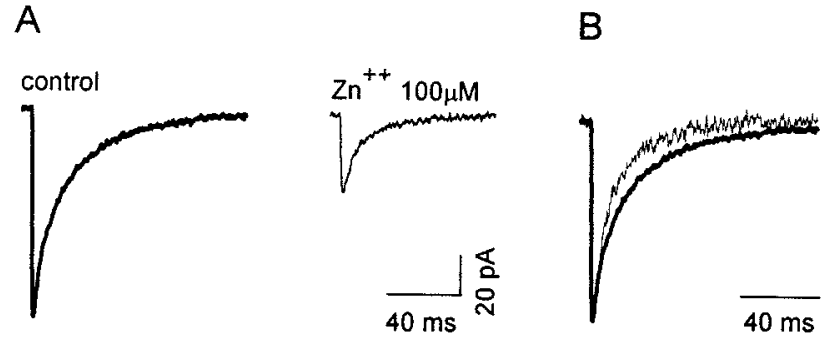

C

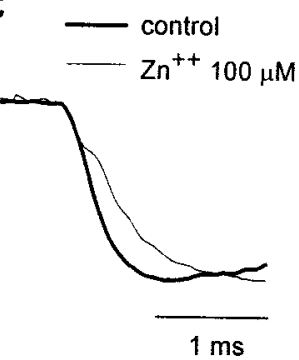

$E$
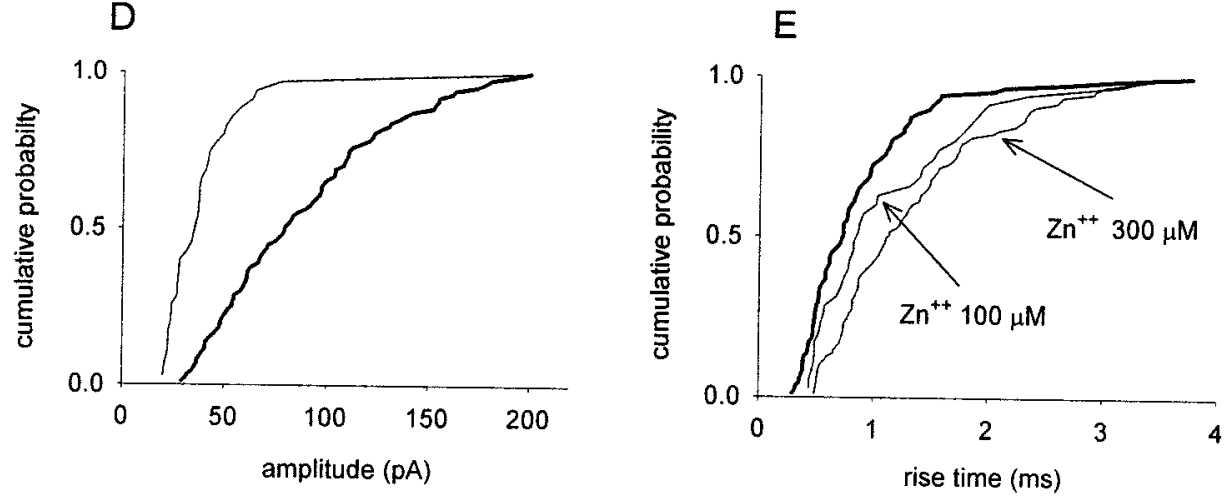

G
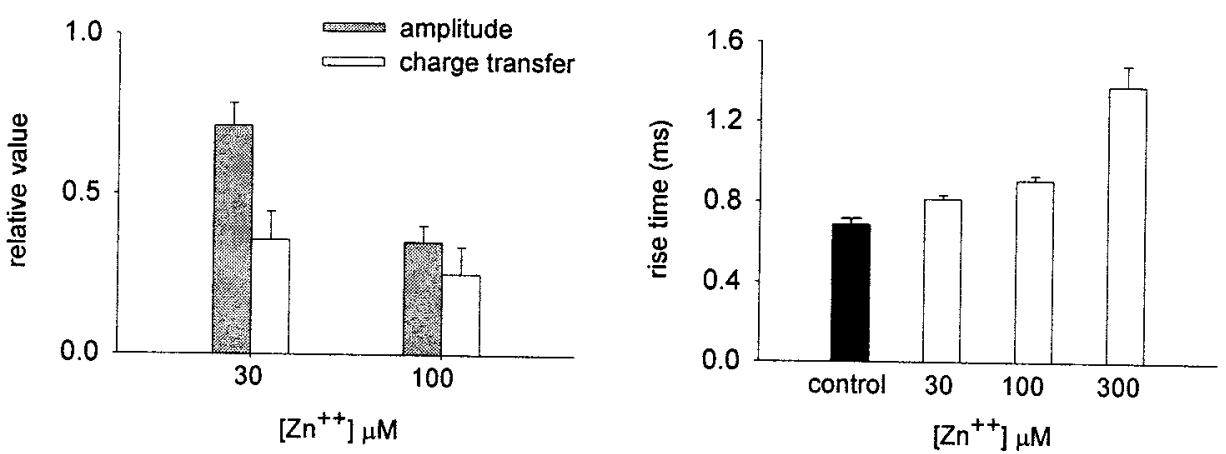

Table 1. Decay kinetics of mIPSCs and GABA-evoked currents

[Zinc] $\mu \mathrm{M}$

\begin{tabular}{|c|c|c|c|c|}
\hline \multirow[b]{2}{*}{ Control } & & \\
\hline & & 30 & 100 & 300 \\
\hline \multicolumn{5}{|l|}{ mIPSCs } \\
\hline$\tau_{1}(\mathrm{msec})$ & $4.7 \pm 0.7$ & $3.5 \pm 0.9$ & $4.6 \pm 0.9$ & $5.7 \pm 2$ \\
\hline $\mathrm{A}_{1}(\%)$ & $42 \pm 3$ & $50 \pm 7$ & $62 \pm 4$ & $60 \pm 8$ \\
\hline$\tau_{2}(\mathrm{msec})$ & $33.7 \pm 3.1$ & $21.1 \pm 4$ & $17.9 \pm 2.8$ & $14.6 \pm 2.7$ \\
\hline \multicolumn{5}{|c|}{ GABA-evoked currents } \\
\hline$\tau_{1}(\mathrm{msec})$ & $4.1 \pm 0.5$ & $6.5 \pm 0.5$ & $5.6 \pm 0.6$ & $3.8 \pm 0.7$ \\
\hline $\mathrm{A}_{1}(\%)$ & $49 \pm 3$ & $53 \pm 1$ & $65 \pm 4$ & $58 \pm 10$ \\
\hline$\tau_{2}(\mathrm{msec})$ & $95.1 \pm 7.8$ & $77.7 \pm 5.1$ & $32.5 \pm 4$ & $16.1 \pm 1.1$ \\
\hline
\end{tabular}

$\mathrm{A} 2=1$-A1. The averages are calculated from at least 12 data values.

\section{$\mathrm{Zn}^{2+}$ affects the kinetics of currents evoked by ultrafast applications of GABA}

One of the major problems in determining the mechanisms of drug action on synaptic currents is that the concentration and time course of synaptic neurotransmitter cannot be easily manipulated precluding standard approaches based on constructions of doseresponse relationships. A recent report (Mozrzymas et al., 1999) has indicated that GABA transient in the synaptic cleft is extremely fast (hundreds of microseconds) and that the crucial requirement to properly mimic synaptic currents is to approach the speed of synaptic agonist changes. This task can be reasonably achieved by ultrafast agonist application system (Jonas, 1995; Jones and Westbrook, 1995; Tia et al., 1996) and in our experiments, the 10-90\% exchange of solution around the open tip of a pipette occurred within $40-80 \mu \mathrm{sec}$.

Figure 2, $A$ and $B$, shows typical current responses evoked by ultrafast application of a saturating concentration of GABA. Similarly to mIPSCs, GABA responses were characterized by a rapid rising phase (Fig. $2 C, E$ ) followed by a biphasic decay, having time constant of $4.1 \pm 0.5$ and $95.1 \pm 7.8 \mathrm{msec}\left(\tau_{\text {fast }}\right.$ and $\tau_{\text {slow }}$, respectively; $n=13)$. As in the case of mIPSCs, $\mathrm{Zn}^{2+}$ induced a dose-dependent reduction of the amplitude and of charge transfer of GABA-induced currents (Fig. $2 A, D$ ). $\mathrm{Zn}^{2+}$ slowed the rise time and accelerated their decay kinetics (Fig. $2 B, D$; Table 1 ). In particular, the faster current decay in $\mathrm{Zn}^{2+}(100 \mu \mathrm{M})$ was associated with a decrease in the area and in the time constant of the slower component (Table 1).

\section{$\mathrm{Zn}^{2+}$ slows the onset kinetics of GABA-induced currents}

Similarly to what observed for mIPSCs, $\mathrm{Zn}^{2+}$ decreased the rate of onset of the currents evoked by rapid GABA application. As shown in Figure 3, the 10-90\% rise time of the current evoked by a saturating concentrations of GABA $(10,30 \mathrm{~mm})$ in the presence of $\mathrm{Zn}^{2+}(100 \mu \mathrm{M})$ was significantly $(p<0.001)$ slower than in control $\left(0.26 \pm 0.01 \mathrm{msec}\right.$ in control vs $0.9 \pm 0.1 \mathrm{msec}$ in $\mathrm{Zn}^{2+} ; n=$ 14). $\mathrm{Zn}^{2+}$-induced reduction in the rate of current onset persisted when GABA concentration was increased from 10 to $30 \mathrm{~mm}$ (Fig. $3 A, B)$.

Activation of $\mathrm{GABA}_{\mathrm{A}}$ receptors (as any other ligand-gated chan- 
A
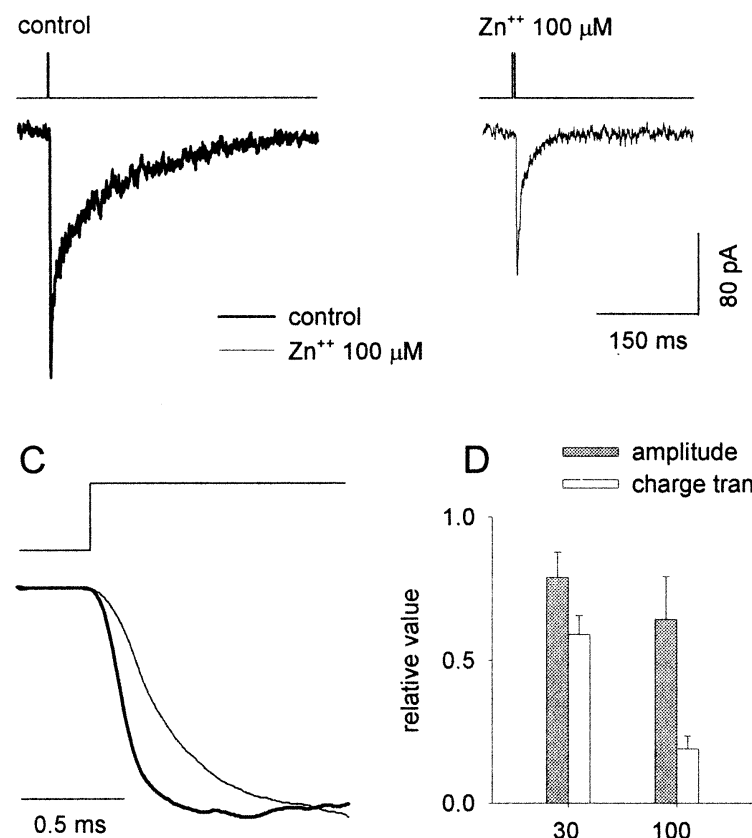

A

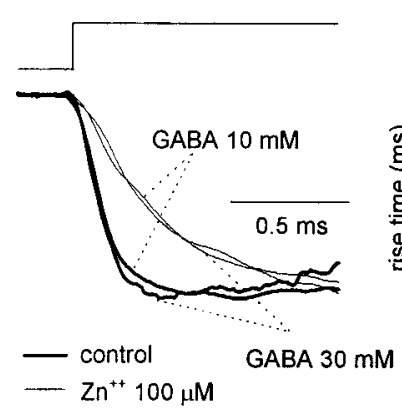

D

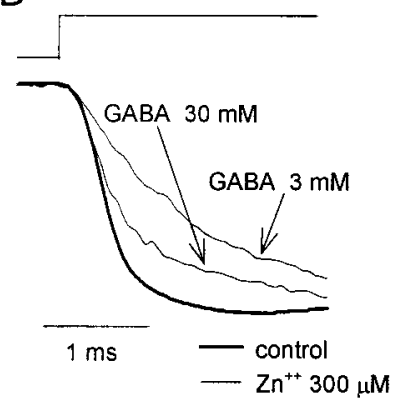

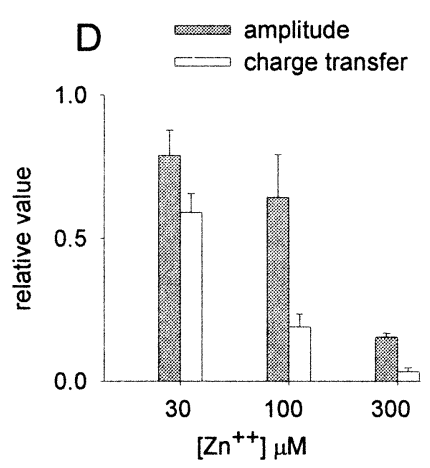

B
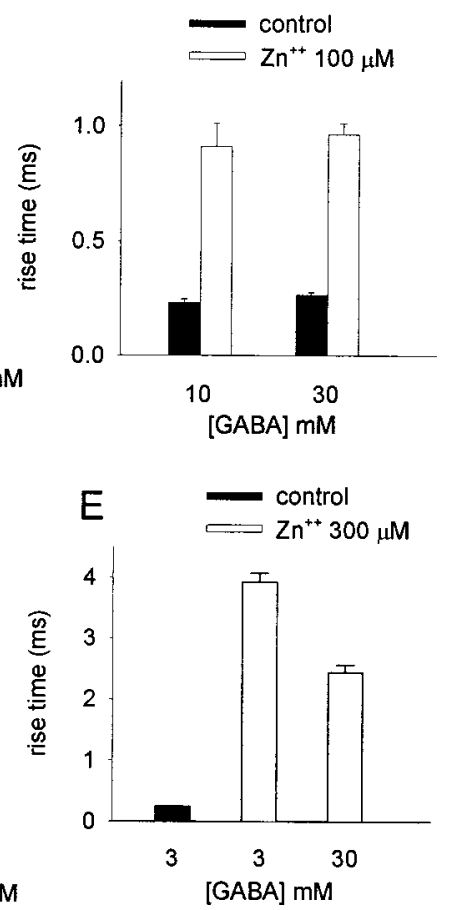

B
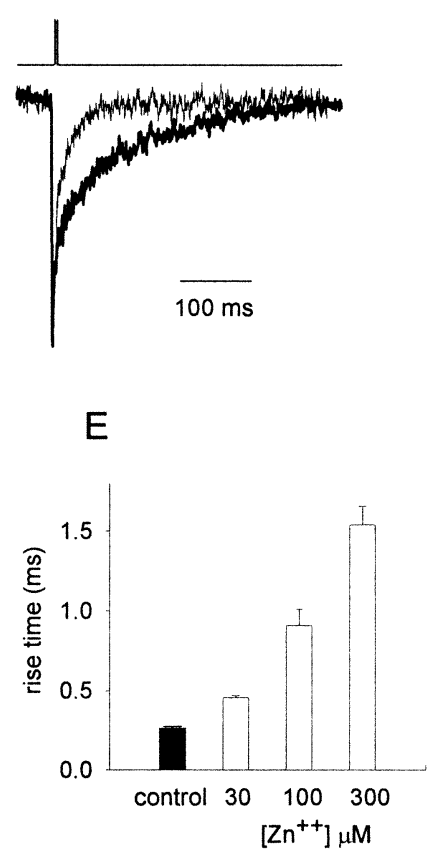

C

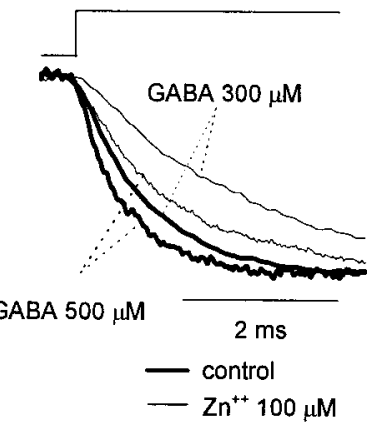

F GABA $3 \mathrm{mM}, \mathrm{Zn}^{++} 300 \mu \mathrm{M}$

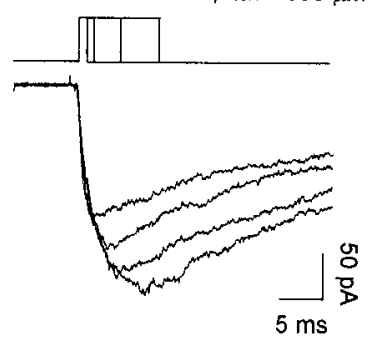

Figure 2. Concentration-dependent effect of $\mathrm{Zn}^{2+}$ on current responses elicited by ultrafast brief GABA applications. $A$, Currents evoked by brief ( $2 \mathrm{msec}$ ) GABA pulses (10 mM, upward deflection in the top trace), in control conditions, and in the presence of $\mathrm{Zn}^{2+}(100 \mu \mathrm{M}) . B$, The two traces in $A$ are normalized and superimposed. $C$, Normalized onset of current responses elicited by GABA $(3 \mathrm{~mm})$ in control conditions (thick) and in the presence of $\mathrm{Zn}^{2+}(100 \mu \mathrm{M}$, thin). $D$, Concentration-dependent effect of $\mathrm{Zn}^{2+}$ on the amplitude (gray columns) and on total charge transfer (white columns) of GABA-evoked currents. Amplitudes and total charge transfers were normalized to control values. $E$, Each column represents the mean $(n=13-26) 10-90 \%$ rise time value of currents elicited by GABA $(10 \mathrm{~mm})$ in control (black) and in the presence of different $\mathrm{Zn}^{2+}$ concentrations (white). nel) consists of at least two steps: binding of the agonist to the receptor and conformational change from bound closed to bound open state. Thus, the investigation of $\mathrm{Zn}^{2+}$ action on the rise time kinetics requires the assessment of $\mathrm{Zn}^{2+}$ effects on these two $\mathrm{GABA}_{\mathrm{A}} \mathrm{R}$ activation components. For this purpose, we have used the Jones and Westbrook (1995) model (see Fig. 7 for the scheme), which after optimization of the rate constants, allowed us to properly express our experimental results in terms of microscopic gating. As predicted by the model, the only process whose kinetics depends on GABA concentration is the binding step (binding rate $\left.=k_{\mathrm{on}} \cdot[\mathrm{GABA}]\right)$. Thus, by changing the concentration of applied GABA, we are able to manipulate this rate constant making it e.g., either rate limiting (at low [GABA]) or much faster than the conformational transition $\left(\beta_{2}\right)$. Moreover, the zinc effect on binding and conformational change $\left(k_{\text {on }}\right.$ and $\left.\beta_{2}\right)$ are expected to be distinguished on the basis of their dependence on [GABA]. Thus, the reduction in the binding rate caused by a decreased $k_{\text {on }}$ value should be compensated by a respective increase in [GABA] while reduction of $\beta_{2}$ would remain unaffected by [GABA]. As shown in Figure 3, $A$ and $B$, the rise times of currents evoked by 10 and $30 \mathrm{~mm}$ GABA in the presence of $100 \mu \mathrm{M} \mathrm{Zn}$ were not different from each other but were significantly slower than those in control conditions. The constant value of rise time at these GABA concentrations indicates that, in these conditions, the conformational step $\left(\beta_{2}\right)$ is rate limiting. Consequently, the slower rise time in the presence of $\mathrm{Zn}^{2+}$ provides evidence that this cation slows the rate 
constant $\beta_{2}$. However, it remains to be elucidated whether $\mathrm{Zn}^{2+}$ affects also the binding step. For this purpose we have recorded the current responses to rapid applications of GABA at concentrations at which binding is rate limiting. Similarly to previous reports (Jones and Westbrook, 1995; Mozrzymas et al., 1999) we have found that saturation of the rise time kinetics was achieved at GABA concentration close to $3 \mathrm{~mm}$. The $10-90 \%$ rise time of responses evoked by low concentrations of GABA ( 0.3 and $0.5 \mathrm{~mm})$ was strongly concentration-dependent and several fold slower (2.19 $\pm 0.07 \mathrm{msec}, n=25$ and $1.79 \pm 0.11 \mathrm{msec}, n=15$, for 0.3 and $0.5 \mathrm{~mm}$ GABA, respectively) than that of currents evoked by saturating [GABA] (compare Fig. $3 A, C$ ). In the presence of $\mathrm{Zn}^{2+}$ $(100 \mu \mathrm{M})$, the rise time increased to $8.29 \pm 0.7 \mathrm{msec}, n=56$ and to $6.62 \pm 0.4, n=28$ for 0.3 and $0.5 \mathrm{~mm}$ GABA, respectively (Fig. $3 C)$. The fact that both in control conditions and in the presence of $\mathrm{Zn}^{2+}$ the rise times at 0.3 and $0.5 \mathrm{~mm}$ GABA were several times slower than at saturating [GABA] clearly indicates that at 0.3 and $0.5 \mathrm{~mm}$ GABA the binding step is predominant and therefore $\mathrm{Zn}^{2+}$ effect on the rise time is mainly caused by $\mathrm{Zn}^{2+}$-induced decrease in the binding rate. Altogether, the use of low and high [GABA] allowed to reveal that the mechanism underlying zinc effects on the rise time kinetics consists of a decrease of both the binding $\left(k_{\text {on }}\right)$ and conformational change $\left(\beta_{2}\right)$ rate constants of $\mathrm{GABA}_{\mathrm{A}}$ receptors. In the quantitative determination of $\mathrm{Zn}^{2+}$ effect on the rate constants using model simulations, $\beta_{2}$ was first determined at high [GABA], and this rate constant was subsequently included in the analysis of the current rise time kinetics at low [GABA] in which $\mathrm{Zn}^{2+}$ effect on both $k_{\text {on }}$ and $\beta_{2}$ has to be considered. Although for the responses evoked by $3 \mathrm{~mm}$ GABA in the presence of $100 \mu \mathrm{M} \mathrm{Zn}^{2+}$, the conformational change step was rate limiting (the rise time of $0.95 \pm 0.07 \mathrm{msec}$ was not accelerated by increase in [GABA]; compare with Fig. $3 B$ ), a higher $\mathrm{Zn}^{2+}$ concentration $(300 \mu \mathrm{M})$ caused an increase in the rise time that could be partially restored by increasing [GABA] to $30 \mathrm{~mm}$ (Fig. $3 D, E)$. The interpretation of these findings is that the increase in $\mathrm{Zn}^{2+}$ concentration to $300 \mu \mathrm{M}$ reduces the rate of binding to such extent that at $3 \mathrm{~mm}$ GABA, the conformational change step $\left(\beta_{2}\right)$ is not any more rate limiting. The increase in [GABA] to $30 \mathrm{~mm}$ accelerates binding sufficiently to make the conformational transition rate limiting again. In these conditions (30 mM GABA and 300 $\mu \mathrm{M} \mathrm{Zn}^{2+}$ ) the rise time considerably increased in comparison to

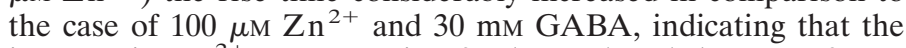
increase in $\mathrm{Zn}^{2+}$ concentration further reduced the rate of conformational transition $\left(\beta_{2}\right)$. The described mechanism whereby $\mathrm{Zn}^{2+}$ modulates the activation kinetics of $\mathrm{GABA}_{\mathrm{A}}$ Rs predicts that this divalent cation may affect the threshold value of GABA concentration below which the binding step becomes rate limiting. Such a prediction is borne out by experiments in which currents induced by varying pulses of GABA $(3 \mathrm{~mm})$ were recorded in the presence of $\mathrm{Zn}^{2+}(300 \mu \mathrm{M})$. Because, as mentioned, 3 mM GABA is saturating, variation of pulse duration from 1 to $10 \mathrm{msec}$ did not affect either the onset kinetics or the amplitude of GABA control responses (data not shown). As shown in Figure $3 F$, in the presence of $\mathrm{Zn}^{2+}(300 \mu \mathrm{M})$, the increase in pulse duration resulted in the increase of current amplitude and rise time. This is a consequence of the fact that at $\mathrm{Zn}^{2+} 300 \mu \mathrm{M}$, the reduction of $k_{\text {on }}$ is so strong that the binding step becomes rate limiting. In addition, in these conditions, the rate of binding becomes too slow to complete this process within $1 \mathrm{msec}$ (as it took place in the absence of $\mathrm{Zn}^{2+}$ ), and for this reason the prolongation of pulse increases the probability of binding leading to a larger response.

\section{$\mathrm{Zn}^{2+}$ affects desensitization of GABA $\mathrm{A}$}

Because it is known that desensitization plays a crucial role in shaping the deactivation kinetics of GABA-evoked currents, a series of experiments have been performed to assess the effects of $\mathrm{Zn}^{2+}$ on this process. To describe the desensitization onset kinetics, long pulses of saturating GABA $(10 \mathrm{~mm})$ were applied in the presence and absence of $\mathrm{Zn}^{2+}$. Application of GABA for $300 \mathrm{msec}$ induced a clearly biphasic desensitization described by time con- stants of $4.9 \pm 0.7$ and $125.9 \pm 17.9 \operatorname{msec}\left(A_{1}=34 \pm 14 \% ; A_{2}=\right.$ $30 \pm 2 \% ; A_{\mathrm{S}}=35 \pm 13 \%, n=10$; Fig. $\left.4 A-C\right)$. Because the slower component is unlikely to significantly affect the time course of synaptic currents, further analysis has been limited to the rapid one, which at pulse duration of $50 \mathrm{msec}$ was predominant $\left(\tau_{1}=\right.$ $4.9 \pm 0.7 \mathrm{msec} ; A=43 \pm 2 \% ; A_{\mathrm{S}}=56 \pm 2 \%$; data not shown). $\mathrm{Zn}^{2+}$ slowed the time constant of the onset and increased the extent of desensitization in a concentration-dependent manner (at $\left.100 \mu \mathrm{M}, \tau_{1}=22.9 \pm 1.2 \mathrm{msec} ; A=56 \pm 4 \% ; A_{\mathrm{S}}=44 \pm 4 \%\right)$.

Paired pulse protocol is commonly used to study the recovery from desensitization kinetics. It needs to be emphasized, however, that in the case in which the unbinding rate $\left(k_{\text {off }}\right.$, see scheme in the Fig. 7) is comparable or slower than the desensitization onset rate $\left(d_{2}\right)$ and opening rate $\left(\beta_{2}\right)$, the experimentally observable recovery from desensitization (i.e., transition from the desensitized state $A_{2} D$ to the activatable state $R$ ) would be delayed by multiple entrances into the desensitized and open states. Thus, in these conditions, the time course of the second peak recovery would reflect not solely the recovery from desensitization but a more complex process including multiple sojourns in the open and desensitized states. Such functional link between unbinding and desensitization has been also proposed to underlie the slow deactivation of GABA-evoked responses (Jones and Westbrook, 1995). In the case of such multiple entrances, it would be expected that after the agonist removal, a proportion of bound receptors would temporarily accumulate in the desensitized state. To test for such possibility, paired responses to brief (1-2 msec) GABA pulses, separated by variable time intervals were recorded. During such a short GABA application (1-2 msec), the onset of the usedependent desensitization is small, and therefore the difference between the first and the second peak (peak1-peak2) is an index of the number of receptors that accumulated in the desensitized state after the first GABA pulse. As shown in the representative example of Figure $4 D$, such double-pulse protocol revealed a strong accumulation in the desensitized state, especially in the absence of $\mathrm{Zn}^{2+}$. When increasing the interstimulus interval, a gradual recovery (calculated using Eq. 4) was observed and, as shown in the summary plot of Figure $4 E, \mathrm{Zn}^{2+}(100 \mu \mathrm{M})$ strongly accelerated this process. However, according to the proposed model, it is still unclear whether this effect was attributable to a slower onset of desensitization, as revealed by the experiments with long GABA pulses, or to faster unbinding kinetics.

In the attempt to "dissect" the effect of $\mathrm{Zn}^{2+}$ on desensitization from that on unbinding kinetics, we have used a weak $\mathrm{GABA}_{\mathrm{A}} \mathrm{R}$ agonist, $\beta$-alanine, which in comparison to GABA has a much slower binding and a faster unbinding kinetics (Jones and Westbrook, 1997). In agreement with a previous study (Jones and Westbrook, 1995), paired pulses (1-2 msec duration) of $\beta$-alanine $(100 \mathrm{~mm})$ did not reveal any accumulation of desensitization for any interval tested (i.e., $I_{1} \cong I_{2}$; data not shown). This finding implies that a $1-2$ msec pulse of $\beta$-alanine is too short to induce any detectable desensitization onset and that this process does not proceed (at variance with the GABA-evoked currents; Fig. 4D) during the deactivation phase (after removal of the agonist). This difference in the progress of desensitization onset during deactivation of GABA- and $\beta$-alanine-induced currents is most likely attributable to a more effective unbinding rate in the case of $\beta$-alanine, which strongly reduces the probability of multiple entrances into the desensitized state. The current response to a single pulse $(1 \mathrm{msec})$ of $\beta$-alanine $(100 \mathrm{~mm})$ was characterized by a very fast, nearly monoexponential decay $\left(\tau_{1}, 3.2 \pm 0.6 \mathrm{msec} ; A_{1}, 89 \pm\right.$ $2 \% ; \tau_{2}, 20.8 \pm 3.08 \mathrm{msec} ; A_{2}, 11 \pm 2 \%, n=10$; Fig. $5 A$ ), indicating that indeed, such functional coupling between desensitization and unbinding rate was practically absent. Longer $(50 \mathrm{msec}) \beta$-alanine pulses induced a desensitization (Fig. 5B) whose onset was well described by a single exponential $\left(\tau=5.9 \pm 1.6 \mathrm{msec} ; A_{1}=41 \pm\right.$ $\left.5 \% ; A_{\mathrm{S}}=59 \pm 5 \%\right)$. Similarly to what was observed for GABAevoked currents, $\mathrm{Zn}^{2+}(100 \mu \mathrm{M})$ significantly $(p<0.001)$ slowed the onset and increased the extent of desensitization of $\beta$-alanineinduced currents $\left(\tau=28.7 \pm 0.6 \mathrm{msec} ; A_{1}=59 \pm 5 \% ; A_{\mathrm{S}}=41 \pm\right.$ 
A

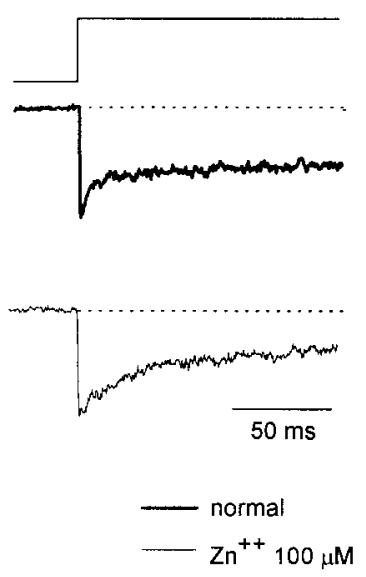

D
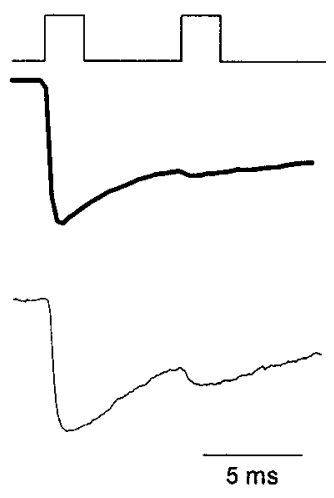

B

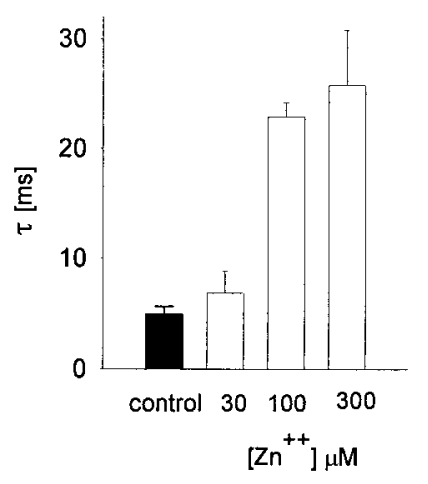

- control

- $\mathrm{Zn}^{++} 100 \mu \mathrm{M}$

E

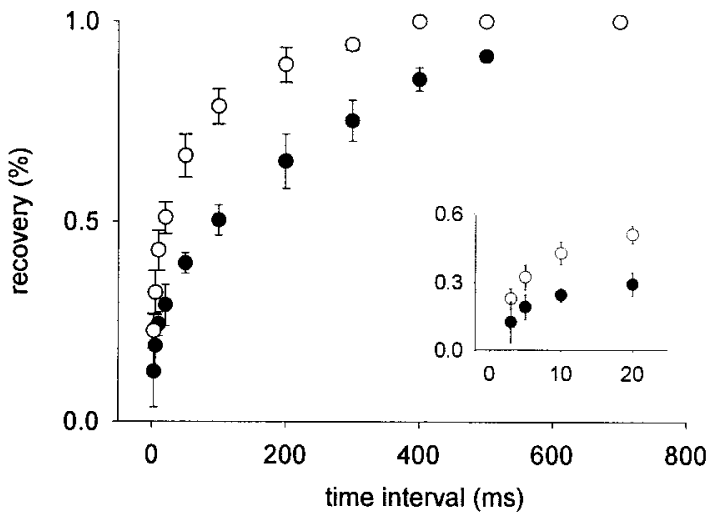

Figure 4. $\mathrm{Zn}^{2+}$ affects desensitization kinetics of GABA-evoked currents. $A$, Normalized currents evoked by GABA $(10 \mathrm{~mm}$, for $300 \mathrm{msec}$ ) in the absence (thick line) and in the presence of $\mathrm{Zn}^{2+}(100 \mu \mathrm{M}$, thin line $)$. $B, C$, Mean $(n=5-11)$ time constant $(\tau)$ desensitization onset and relative area $\left(A_{1}\right)$ of GABA responses $(10 \mathrm{~mm})$ evoked in the absence (black) and in the presence (white) of different $\mathrm{Zn}^{2+}$ concentrations. $D$, Paired brief $(2 \mathrm{msec})$ GABA pulses $(10 \mathrm{~mm})$ elicited at $5 \mathrm{msec}$ interval in the absence (thick line) and in the presence of $\mathrm{Zn}^{2+}(100 \mu \mathrm{M}$, thin line). Note that $\mathrm{Zn}^{2+}$ strongly accelerated the recovery of currents evoked by the second pulse. $E$, Normalized recovery of the second peak evoked in the absence (open circles) or in the presence of $\mathrm{Zn}^{2+}$ $(100 \mu \mathrm{M}$, closed circles). Each point represents the mean $(n=5-9)$. In the inset, a part of the graph has been enlarged to show effects of $\mathrm{Zn}^{2+}$ at shorter time intervals.
$5 \%$ ). Because, as explained above, the desensitization onset would be practically terminated after removal of $\beta$-alanine, the recovery from desensitization was studied using a standard approach based on the application, at different time intervals, of a long $(50 \mathrm{msec})$ $\beta$-alanine conditioning pulse (to induce the use-dependent desensitization) followed by a test pulse. As shown in Figure 5, $B$ and $C$, $\mathrm{Zn}^{2+}(100 \mu \mathrm{M})$ strongly slowed the recovery from desensitization. This effect was exactly the opposite of what was observed when double short GABA pulses were applied (Fig. 4E). Moreover, whereas in $\mathrm{Zn}^{2+}(100 \mu \mathrm{M})$ the recovery from desensitization of $\beta$-alanine-induced currents was negligible within the first $20 \mathrm{msec}$ (Fig. $5 C$ ), the recovery of current elicited by the second short GABA pulse was very pronounced $(\sim 50 \%$ recovery after $20 \mathrm{msec}$; Fig. 4, inset). These findings clearly rule out the possibility that zinc-induced acceleration of the recovery of currents induced by short GABA pulses (Fig. 4D) is caused by changes in recovery from desensitization. Both the faster recovery of responses to short GABA pulses and the faster deactivation kinetics in zinc are compatible with a decrease in the desensitization onset. It remains, however, still to be elucidated whether $\mathrm{Zn}^{2+}$ affects also the unbinding rate of $\mathrm{GABA}_{\mathrm{A}} \mathrm{Rs}$. As explained in detail below, the model simulations provide indirect evidence that unbinding rate is being increased in the presence of zinc.

\section{$\mathrm{Zn}^{2+}$ does not act as a fast competitive antagonist}

Based on the data presented above, the effects of $\mathrm{Zn}^{2+}$ on the rising phase of current responses to rapid GABA applications may arise from a decrease in the rate constants of binding $\left(k_{\text {on }}\right)$ and of conformational change $\left(\beta_{2}\right)$. Alternatively, a competitive block of GABA-binding site by $\mathrm{Zn}^{2+}$ could account for the slower onset. In such a case, the activation of $\mathrm{GABA}_{\mathrm{A}}$ Rs would be delayed by the time needed for $\mathrm{Zn}^{2+}$ to unbind from GABA-binding site. From the difference in the rise time of currents evoked by saturating
GABA, in control conditions and in the presence of $100 \mu \mathrm{M} \mathrm{Zn}^{2+}$ (Fig. $3 A$ ), it can be deduced that the dissociation of zinc should occur very quickly (within $0.5-0.6 \mathrm{msec}$ ). To assess the time of interaction between $\mathrm{Zn}^{2+}$ and $\mathrm{GABA}_{\mathrm{A}} \mathrm{Rs}$, current responses to coapplication of GABA and $\mathrm{Zn}^{2+}$ were examined. As shown in the Figure $6, A$ and $B$, the time course of currents evoked by short (1-2 $\mathrm{msec})$ pulses of GABA (10 mM) alone or coapplied with $\mathrm{Zn}^{2+}(100$ $\mu \mathrm{M})$ were indistinguishable, indicating that $1-2 \mathrm{msec}$ is too short for $\mathrm{Zn}^{2+}$ to exert its effect on GABA $\mathrm{A}$. Moreover, when a conditioning pulse of GABA coapplied with $\mathrm{Zn}^{2+}$ (for $40 \mathrm{msec}$ ) was followed (after $40 \mathrm{msec}$ of wash) by a second short ( $5 \mathrm{msec}$ ) test pulse, the onset of the latter response was slower than that of the first one (Fig. 6C,D). The rise time kinetics of the test response was very similar to that observed when the current was evoked after pre-equilibrating GABA receptors with $\mathrm{Zn}^{2+}$ (Fig. $3 A$ ). This indicates that a $40 \mathrm{msec}$ duration of the conditioning pulse is sufficient for zinc to affect $\mathrm{GABA}_{\mathrm{A}} \mathrm{Rs}$, and $40 \mathrm{msec}$ of wash with a $\mathrm{Zn}^{2+}$-free medium is too short for $\mathrm{Zn}^{2+}$ removal. When applying the same protocol in the absence of zinc ( $40 \mathrm{msec}$ conditioning pulse followed after $40 \mathrm{msec}$ by a test pulse), the rise time of the two pulses were indistinguishable (data not shown).

A further indication that the kinetics of zinc interaction with $\mathrm{GABA}_{\mathrm{A}} \mathrm{Rs}$ is too slow to explain our observations in terms of competitive antagonism came from experiments in which short GABA pulses (10 mu without $\mathrm{Zn}^{2+}$ ) were applied for $2 \mathrm{msec}$ to outside-out patches of membranes pre-equilibrated in $\mathrm{Zn}^{2+}(100$ $\mu \mathrm{M})$. As seen in the Figure $6 E$, the rise time of such currents $(0.9 \pm$ 0.01 msec; $p>0.5 ; n=8$ ) did not differ from that obtained in the continuos presence of $\mathrm{Zn}^{2+}$ (Fig. 2).

\section{Model simulations}

To provide a better quantitative description of the $\mathrm{Zn}^{2+}$ effects on $\mathrm{GABA}_{\mathrm{A}}$ receptors, model simulations were used (Fig. $7 F$ ). We 
A

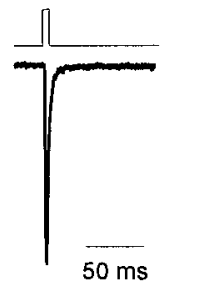

B
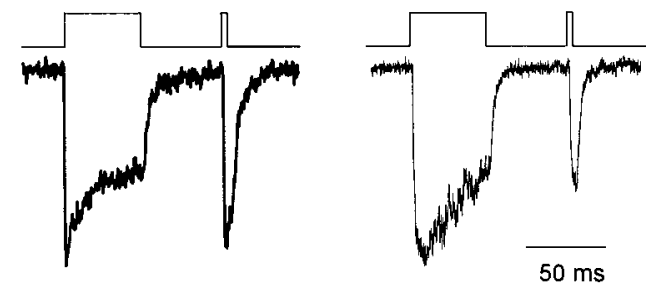

- $\beta$-alanine

$\beta$-alanine in $\mathrm{Zn}^{++} 100 \mu \mathrm{M}$

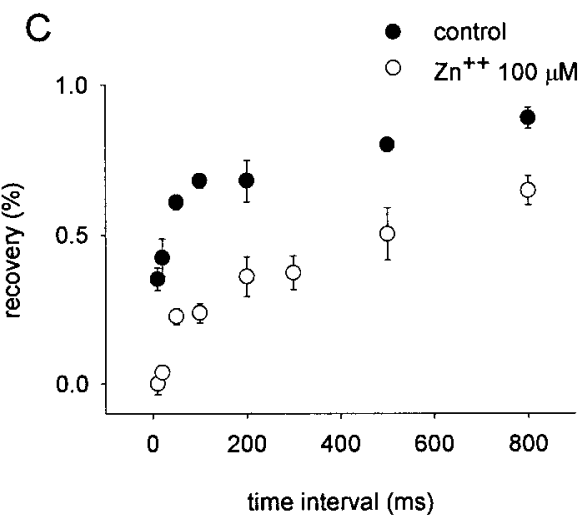

Figure 5. $\mathrm{Zn}^{2+}$ slows the recovery from desensitization. Current response elicited by a brief $(2 \mathrm{msec})$ pulse of $\beta$-alanine $(100 \mathrm{~mm})$. B. Conditioning pulse of $\beta$-alanine ( $100 \mathrm{~mm}$ ) followed by a test pulse with a time interval of $50 \mathrm{msec}$, in control (thick line) and in the presence of $\mathrm{Zn}^{2+}(100 \mu \mathrm{M}$, thin line). $C$, Normalized recovery from desensitization of $\beta$-alanine currents evoked in the absence (open circles) or in the presence of $\mathrm{Zn}^{2+}(100 \mu \mathrm{M}$, closed circles). Each point represents the mean $(n=7-56)$.

used the kinetic model proposed by Jones and Westbrook (1995) as the minimum requirement to properly reproduce the basic properties of $\mathrm{GABA}_{\mathrm{A}}$ Rs such as two binding sites (suggested by Hill slope analysis), saturation of the onset rate at high [GABA], desensitization process, and slow deactivation resulting from the functional link between desensitization and unbinding rate. This model fairly reproduces the behavior of the system when applying various experimental protocols, and its relative simplicity enabled us to estimate most of crucial rate constants in strict reference to the experimental data.

The analysis of the rise time kinetics at saturating GABA concentrations $(\geq 3 \mathrm{~mm})$ revealed the rate constant of the conformational change from the bound closed to the bound open receptor $\left(\beta_{2}\right)$. Once the value of $\beta_{2}$ was determined, it was included in the rise time analysis at lower GABA doses, allowing us to precisely determine the value of the binding rate $k_{\mathrm{on}}$. The estimation of rate constant values for the onset $\left(d_{2}\right)$ and the recovery $\left(r_{2}\right)$ from desensitization were based on the respective experiments in which kinetics of this process was investigated (Figs. 4, 5). The $\alpha_{2}$ and $k_{\text {off }}$ rate constants have been optimized to reproduce the decaying phase of the currents evoked by brief, saturating pulses of GABA. In our simulations the rate constants for transitions of single bound receptors have been adopted from Jones and Westbrook (1995) model, but because of their small values, the probability of occupancy of these states was low.

Subsequently, effects of $\mathrm{Zn}^{2+}(100 \mu \mathrm{M})$ on current kinetics were included in the analysis, and the values of $k_{\text {on }}, \beta_{2}, d_{2}$, and $r_{2}$ were determined. However, our experimental evidence was insufficient to assess the effect of $\mathrm{Zn}^{2+}$ on the unbinding rate $\left(k_{\text {off }}\right)$. In particular, it was not clear whether a faster recovery of second pulse evoked by brief GABA applications (Fig. 4) was solely attributable to a reduced entrance into the desensitized state (decreased $d_{2}$ ) or
A

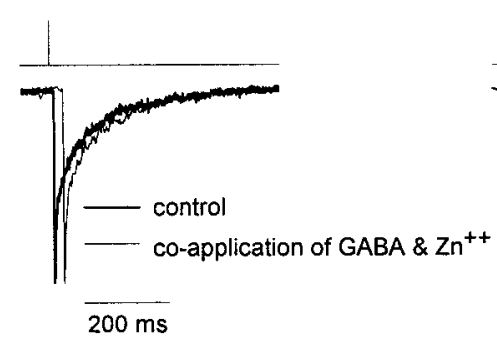

C

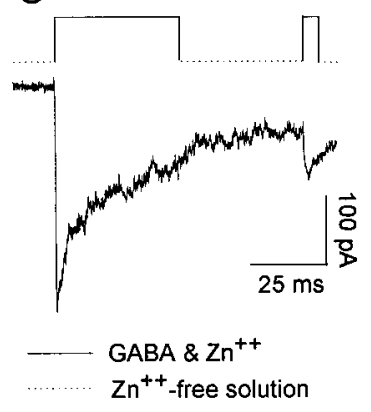

E

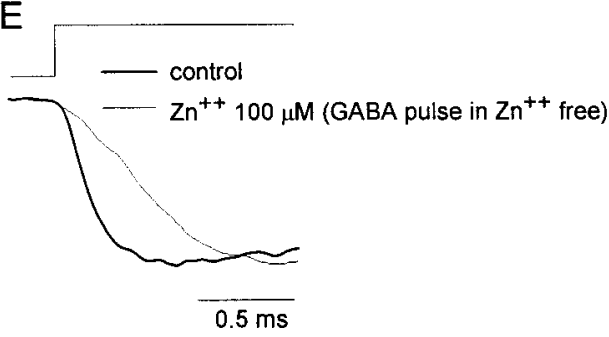

Figure 6. Onset and decay kinetics of current responses elicited by coap-

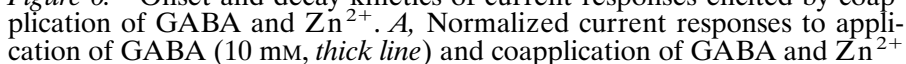
$(100 \mu \mathrm{M}$, thin line $)$. For clarity the two responses have been slightly separated. Note that the two responses almost overlap. $B$, The onsets of the responses shown in $A$ are illustrated at an expanded time scale. $C$, Conditioning pulse $(40 \mathrm{msec})$ of GABA $(10 \mathrm{mM})$ and $\mathrm{Zn}^{2+}(100 \mu \mathrm{M})$, followed at $40 \mathrm{msec}$ interval by a short $(5 \mathrm{msec})$ test pulse of GABA and $\mathrm{Zn}^{2+}$. The dotted line indicates perfusion with a $\mathrm{Zn}^{2+}$-free solution. $D$, Onset of the conditioning and test responses shown in $C$ are superimposed and shown with an expanded time scale. $E$, Responses to brief ( $2 \mathrm{msec}$ ) GABA pulses $\left(10 \mathrm{~mm}\right.$ in the absence of $\mathrm{Zn}^{2+}$ ), applied either in control conditions (thick line) or after pre-equilibration in $\mathrm{Zn}^{2+}$-containing solution.

was also a consequence of higher unbinding rate. Our model simulations indicate that both mechanisms are involved. We found that when keeping $k_{\text {off }}$ unchanged (0.1-0.2 $\mathrm{msec}^{-1}$ ) the extent of recovery of the second peak in the presence of $\mathrm{Zn}^{2+}$ (Fig. 4) could be reproduced by reducing the $d_{2}$ rate constant from 1-2 to $0.1-0.2 \mathrm{msec}^{-1}$. However, such low values of $d_{2}$ precluded the reproduction of $\mathrm{Zn}^{2+}$-induced increase in the steady-state fraction of the desensitized state (Fig. 4A). Apparently, the entrance into the desensitized state at such low $d_{2}$ values was too slow to permit the accumulation of receptors in this state despite a strongly reduced recovery rate $\left(r_{2}\right)$. A good quantitative reproduction of both accelerated recovery (like that shown in Fig. 4) and the increased extent of desensitization in $\mathrm{Zn}^{2+}$ was obtained when an increase in the unbinding rate $k_{\text {off }}$ was included (Fig. 7B,C).

Altogether, the experimental data and model simulations indicate that the $\mathrm{Zn}^{2+}$ mechanism on $\mathrm{GABA}_{\mathrm{A}}$ receptors includes a decrease in the rate constants determining binding $\left(k_{\text {on }}\right)$, conformational transition from closed to open state $\left(\beta_{2}\right)$, desensitization onset $\left(d_{2}\right)$, and recovery $\left(r_{2}\right)$ as well as an increase in the unbinding rate $\left(k_{\text {off }}\right)$. Such modulation of $\mathrm{GABA}_{\mathrm{A}} \mathrm{R}$ gating was sufficient to reproduce fairly well the reduction in amplitude (Fig. $7 A$ ), the increase in desensitization extent (Fig. $7 B$ ), the decrease in the rate 
A
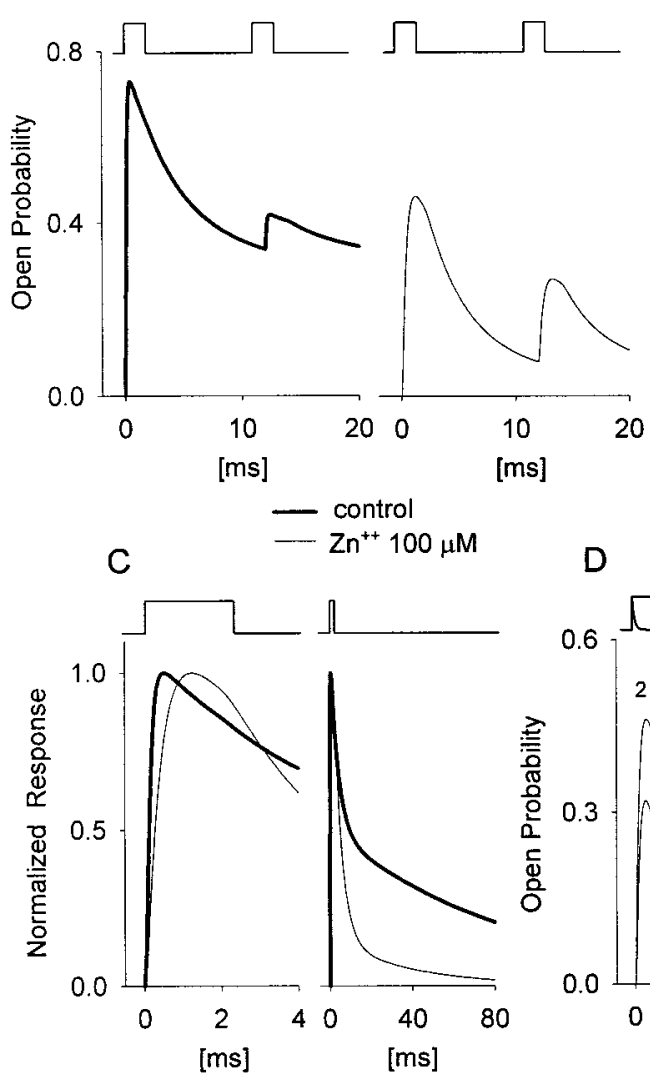

$\mathrm{F}$

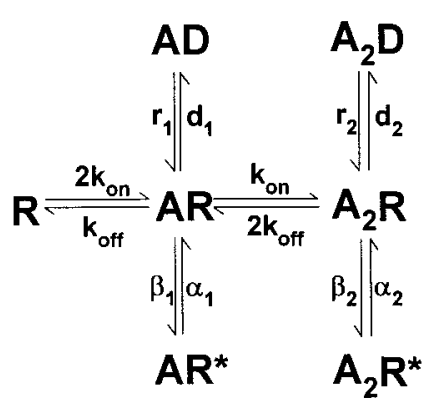

B

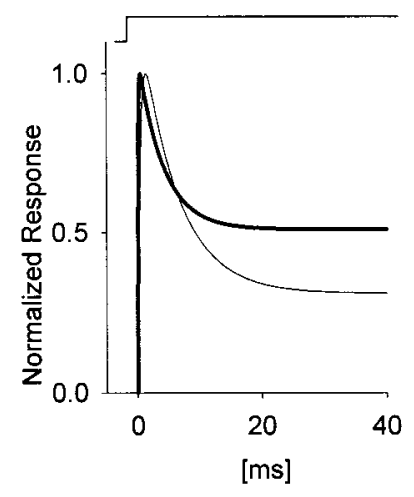

E
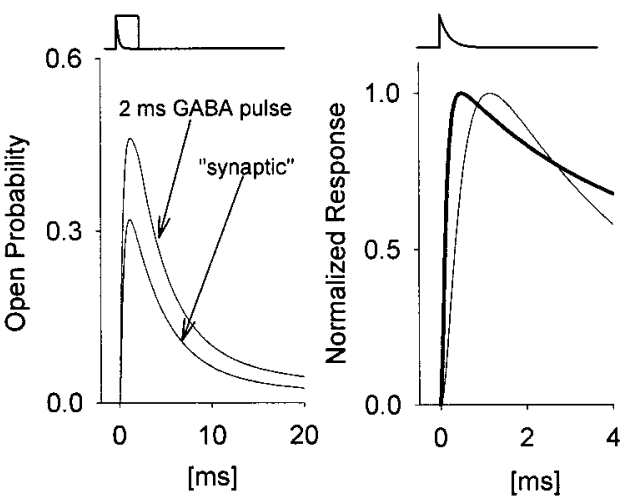

G

\begin{tabular}{|c|c|c|}
\hline costants & control & $100 \mu \mathrm{M} \mathrm{Zn}$ \\
\hline $\mathrm{k}_{\text {on }}\left[\mathrm{ms}^{-1} \mathrm{mM}^{-1}\right]$ & $8-12$ & $1.5-3$ \\
\hline $\mathrm{k}_{\text {off }}\left[\mathrm{ms}^{-1}\right]$ & $0.11-0.2$ & $0.2-0.3$ \\
\hline$\beta_{1}\left[\mathrm{~ms}^{-1}\right]$ & 0.2 & 0.2 \\
\hline$\alpha_{1}\left[\mathrm{~ms}^{-1}\right]$ & 1.1 & 1.1 \\
\hline $\mathrm{d}_{1}\left[\mathrm{~ms}^{-1}\right]$ & 0.013 & 0.013 \\
\hline $\mathrm{r}_{1}\left[\mathrm{~ms}^{-1}\right]$ & 0.00013 & 0.00013 \\
\hline$\beta_{2}\left[\mathrm{~ms}^{-1}\right]$ & $6-10$ & $1.2-1.5$ \\
\hline$\alpha_{2}\left[\mathrm{~ms}^{-1}\right]$ & 1 & 1 \\
\hline $\mathrm{d}_{2}\left[\mathrm{~ms}^{-1}\right]$ & $1-2$ & $0.4-1$ \\
\hline $\mathrm{r}_{2}\left[\mathrm{~ms}^{-1}\right]$ & $0.08-0.15$ & $0.02-0.05$ \\
\hline
\end{tabular}

Figure 7. Model simulation of $\mathrm{Zn}^{2+}$ effects on $\mathrm{GABA}_{\mathrm{A}}$ receptors. For simulation of control recordings the parameters are $k_{\text {on }}=8 \mathrm{msec} / \mathrm{mM}, k_{\text {off }}=0.13$ $\operatorname{msec}^{-1}, \beta_{2}=8 \mathrm{msec}^{-1}, \alpha_{2}=1 \mathrm{msec}^{-1}, d_{2}=1.5$ $\mathrm{msec}^{-1}, r_{2}=0.15 \mathrm{msec}^{-1}$, and for recordings in $\mathrm{Zn}^{2+}, k_{\mathrm{on}}=2 \mathrm{msec} / \mathrm{mm}, k_{\text {off }}=0.25 \mathrm{msec}^{-1}, \beta_{2}=1.5$ $\mathrm{msec}^{-1}, \alpha_{2}=1 \mathrm{msec}^{-1}, d_{2}=0.5 \mathrm{msec}^{-1}$, and $r_{2}=$ $0.04 \mathrm{msec}^{-1}$. The values of the rate constants for singly bound receptors were adopted from Jones and Westbrook (1995) and were assumed not to be affected by zinc. $A$, Simulation of current responses to paired pulses of $10 \mathrm{~mm}$ GABA ( $2 \mathrm{msec}$ pulse duration at $10 \mathrm{msec}$ time interval) in control (thick line) and in the presence of $\mathrm{Zn}^{2+}(100 \mu \mathrm{M}$, thin line $) . B$, Simulation of zinc effects on desensitization onset. Note the $\mathrm{Zn}^{2+}$ decreased the rate and increased the extent of desensitization. $C$, Normalized rise (left) and decay time (right) of GABA response $(10 \mathrm{~mm})$ in the presence or absence of $\mathrm{Zn}^{2+} . \mathrm{Zn}^{2+}$-induced reduction of the onset rate and acceleration of the decay is clearly reproduced. $D$, Current responses in the presence of $\mathrm{Zn}^{2+}$ evoked by "synaptic" GABA application $[A \cdot \exp (-t / \tau) ; A=5 \mathrm{mM}, \tau=0.2 \mathrm{msec}]$ and to a $2 \mathrm{msec}$ pulse of $5 \mathrm{~mm}$ GABA. Similar to the experimental results, a larger reduction was observed in the case of "synaptic" response. E, Simulation of rise time kinetics of the "synaptic" responses to GABA in the presence (thin line) and the absence of $\mathrm{Zn}$ (thick line). F, Kinetic model (Jones and Westbrook, 1995). $G$, Values of the rate constants reproducing the current responses in the control conditions and in the presence of $100 \mu \mathrm{M} \mathrm{Zn}$. of current onset, and acceleration of decay (Fig. 7C) of GABAinduced currents. Model simulation of the current responses to brief GABA applications provided further evidence for an increase in the unbinding rate by $\mathrm{Zn}^{2+}$. When assuming the control $k_{\mathrm{off}}$ value and desensitization onset $\dot{d}_{2}$ sufficiently low $\left(0.1-0.2 \mathrm{msec}^{-1}\right)$ to reproduce the recovery in double short pulse experiments (Fig. 4 ), the slow deactivation component was much longer than that observed in the present experiments $(>50 \mathrm{msec}$ vs $\sim 35 \mathrm{msec}$ in the present experiments). When increasing the value of the unbinding rate to $0.2-0.3 \mathrm{msec}^{-1}$, a good reproduction of deactivation kinetics was obtained. As mentioned, the rate constant $\alpha_{2}$ was deduced from formal fitting of model predictions to the experimental data. Our analysis did not provide any obvious indication that $\mathrm{Zn}^{2+}$ affects this rate constant. However, we cannot exclude that a more detailed analysis (e.g., at the single-channel level) would reveal such effect.

Although at $30 \mu \mathrm{M} \mathrm{Zn}{ }^{2+}$ the amplitude reductions of mIPSCs and of currents evoked by rapid GABA applications were similar,

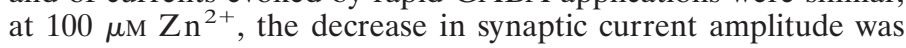

much stronger (compare Figs. $1 F, 2 D$ ). This discrepancy could be attributable to differences in synaptic and extrasynaptic receptors (Banks and Pearce, 2000) or to differences in nonequilibrium conditions of receptor activation in the synapse or in excised patch recordings (Mozrzymas et al., 1999). Recently, it has been reported that the predominant component of the time course of agonist clearance in the synaptic cleft is in the range of hundreds of microseconds, and the concentration of GABA at the peak of synaptic response is $>3 \mathrm{~mm}$ (Mozrzymas et al., 1999). To clarify this issue, $\mathrm{Zn}^{2+}$ effect was simulated on current responses to "synaptic" GABA application ([GABA] $=A \cdot \exp (-t / \tau) ; A=5$ $\mathrm{mm} ; \tau=0.2 \mathrm{msec})$ and to a $2 \mathrm{msec}$ pulse of GABA ( $5 \mathrm{~mm})$. As shown in Figure $7 D$, the reduction of current evoked by "synaptic" application of GABA was considerably stronger. When assuming a faster clearance (e.g., $\tau=0.1 \mathrm{msec}$ ), the difference was even larger (data not shown). A simple explanation of this finding is that in conditions in which the binding rate is strongly reduced by $\mathrm{Zn}^{2+}$, the exposure of receptors to synaptically released GABA becomes too short to complete the binding step. Clearly, a considerably 
longer application of GABA ( 2 msec pulse) would increase the proportion of bound receptors giving rise to larger amplitude responses. This finding emphasizes the importance of nonequilibrium conditions of postsynaptic receptor activation in determining the pharmacological modulation of synaptic currents.

The model simulations have been also performed to see whether the putative time course of synaptic GABA might influence $\mathrm{Zn}^{2+}$ effect on mIPSC rise time. As seen in Figure 7E, in agreement with our experimental observations (Fig. 1), the rise time of normalized responses to "synaptic" GABA application was significantly increased in the presence of $\mathrm{Zn}^{2+}$.

\section{DISCUSSION}

The major finding of the present work is that $\mathrm{Zn}^{2+}$, a divalent cation known to be co-released during synaptic transmission, affects mIPSCs by allosteric modulation of $\mathrm{GABA}_{\mathrm{A}}$ receptors. On the basis of our kinetic analysis, the reduction of amplitude, the decrease in the onset rate, and the acceleration of decay of mIPSCs by $\mathrm{Zn}^{2+}$, can be consistently explained in terms of modulation of $\mathrm{GABA}_{\mathrm{A}} \mathrm{R}$ microscopic gating. Similar to our results, it has been reported that, in rat neocortical pyramidal cells, $\mathrm{Zn}^{2+}$ reduces the decay time, peak amplitude, and rate of rise of mIPSCs without affecting their frequency (DeFazio and Hablitz, 1998). Although these authors claimed that $\mathrm{Zn}^{2+}$ effect was consistent with a reduction in the affinity of the receptor for GABA possibly via a "mixed antagonism" as observed for recombinant $\alpha 1 \beta \gamma 2$ receptors (Gingrich and Burkat, 1998; Krishek et al., 1998), they did not explore the effect of $\mathrm{Zn}^{2+}$ on $\mathrm{GABA}_{\mathrm{A}} \mathrm{R}$ kinetics. The use of the ultrafast perfusion system enabled us to get an insight into the mechanisms of drug-receptor interaction under nonequilibrium conditions similar to those presumably occurring in the synapse. However, even if the current responses to fast GABA application reproduced the major kinetic characteristics of mIPSCs, in agreement with other reports (Galarreta and Hestrin, 1997; Jones and Westbrook, 1997; Mozrzymas et al., 1999; Perrais and Ropert, 1999), synaptic currents were characterized by a faster decay. The source of this discrepancy could arise either from the faster agonist clearance from the cleft in the case of mIPSCs (Mozrzymas et al., 1999) or from differences between $\mathrm{GABA}_{\mathrm{A}} \mathrm{Rs}$ in excised patches and the synaptic ones (Banks and Pearce, 2000). Moreover, the slower onset kinetics of mIPSCs observed in control conditions in comparison to that of GABA-evoked responses (Figs. 1G, 2E) could be attributed to electronic filtering, asynchronous multivesicular release from a single site (Auger and Marty, 2000), and/or changes in receptor subtypes.

To our knowledge, the present report is the first one in which a decrease in binding $\left(k_{\text {on }}\right)$ and in conformational change $\left(\beta_{2}\right)$ rate constants have been demonstrated to underlie the effect of $\mathrm{Zn}^{2+}$ on the rising phase of mIPSC and of GABA-evoked currents. In previous studies such a mechanism has not been described, probably because slower drug application systems precluded the resolution of kinetic changes at submillisecond time scale.

Our results provide evidence that the mechanism underlying the effect of $\mathrm{Zn}^{2+}$ on mIPSCs decay is related to a slower desensitization kinetics (both onset and recovery) and to the increase in the unbinding rate. In contrast to the present findings, Berger et al. (1998) have reported that $\mathrm{Zn}^{2+}$ enhanced the desensitization onset and proposed that this effect underlies a faster current deactivation in zinc. A possible reason for this discrepancy is that Berger et al. (1998) estimated the effects of $\mathrm{Zn}^{2+}$ on the desensitization by coapplying GABA and $\mathrm{Zn}^{2+}$. In these conditions, the desensitization onset would be "accompanied" by the ongoing inhibitory $\mathrm{Zn}^{2+}$ effect on $\mathrm{GABA}_{\mathrm{A}} \mathrm{Rs}$.

Our double pulse experiments provide an important methodological indication that the recovery inferred from the amplitude of the second response is strongly dependent on the unbinding rate because the slow unbinding favors multiple entrances into the desensitized state. This implies that the classical double pulse protocol is an adequate tool to determine the recovery from de- sensitization only when the agonist unbinds sufficiently fast to make negligible the probability of such multiple entrances.

Whereas the effects of $\mathrm{Zn}^{2+}$ on $k_{\text {on }}, \beta_{2}, d_{2}$, and $r_{2}$ rate constants were directly supported by experimental evidence, the $\mathrm{Zn}^{2+}$. induced increase in $k_{\text {off }}$ was deduced from model simulations. In the case of $\mathrm{Zn}^{2+}$-induced reduction of $k_{\text {on }}$, an increase in $k_{\text {off }}$ would be expected because it is known that a decrease in the affinity of $\mathrm{GABA}_{\mathrm{A}} \mathrm{Rs}$ is associated with a decrease in binding and an increase in the unbinding rate constants (Jones et al., 1998). Similarly, in our previous study (Mozrzymas et al., 1999) chlorpromazine-induced reduction of $k_{\text {on }}$ was accompanied by an increase in $k_{\text {off }}$. It appears thus that when altering the strength of binding, the changes in $k_{\text {on }}$ and in $k_{\text {off }}$ are negatively correlated.

The $\mathrm{Zn}^{2+}$-induced reduction of desensitization onset and increase in its extent is consistent with a strong slowing of recovery from desensitization. Such slower exit would favor the accumulation of desensitized receptors leading to a larger steady-state proportion of receptors in this state. On the basis of single-channel studies, it has been proposed that $\mathrm{Zn}^{2+}$ stabilizes the receptor in the closed state (Smart et al., 1994). It is possible that this observation reflects, at least in part, prolonged "sojourns" in the desensitized state caused by the slower receptor exit from this conformation. Single-channel studies have also shown that $\mathrm{Zn}^{2+}$ reduces the opening frequency with no evidence of a flickering block (Legendre and Westbrook, 1991; Smart, 1992; Kilic et al., 1993). As suggested by Krishek et al. (1998) and, in line with the present experiments, this observation favors the hypothesis that $\mathrm{Zn}^{2+}$ might interact with an allosteric modulatory site located on the extracellular domain of the $\mathrm{GABA}_{\mathrm{A}}$ receptor.

In our previous study (Mozrzymas et al., 1999) we found that chlorpromazine (CPZ) strongly reduced the amplitude of mIPSCs without any clear effect on the rise time kinetics. The explanation of this finding is that CPZ affects only the binding/unbinding kinetics, and the synaptic GABA transient is too short to reveal the slower current onset. In the present study, however, $\mathrm{Zn}^{2+}$ caused a marked increase in the rise time of mIPSCs, and this effect was well reproduced by model simulations. The explanation for the different effect of $\mathrm{Zn}^{2+}$ and CPZ on mIPSC rise time lies in $\mathrm{Zn}^{2+}$-induced reduction in the rate constant $\beta_{2}$ that was unaffected by CPZ. Thus, the reduction of the binding rate by CPZ strongly diminished the recruitment of bound receptors during the synaptic GABA transient, but those receptors that bound GABA proceeded to the open state with normal (i.e., control) kinetics described by the $\beta_{2}$ rate constant. On the contrary, in $\mathrm{Zn}^{2+}$, the transition from bound closed to bound open conformation was slowed (smaller $\beta_{2}$ value), giving rise to a slower mIPSCs onset in spite of a very transient synaptic GABA application.

The experiments presented in Figure 6 provide clear evidence that the kinetics of interaction between $\mathrm{Zn}^{2+}$ and $\mathrm{GABA}_{\mathrm{A}}$ receptors is too slow to explain the observed $\mathrm{Zn}^{2+}$ effects in terms of competitive antagonisms. The noncompetitive mechanism of $\mathrm{GABA}_{\mathrm{A}}$ receptors inhibition is additionally supported by the fact that at low $\mathrm{Zn}^{2+}$ concentrations $(\leq 30 \mu \mathrm{M})$ no evidence for a biphasic rise time kinetics was observed. Thus, when applying a saturating dose of agonist, the nonoccupied receptors would be activated with normal kinetics, and the activation of occupied ones would be slowed by the unbinding of the antagonist giving rise to a biphasic onset. This concept has been used for studying the time course of synaptic transmitter at glutamatergic synapses using quickly dissociating competitive antagonists (Clements et al., 1992).

In the case of sustained neuronal activity, a local increase in $\mathrm{Zn}^{2+}$ concentration, caused by release from glutamatergic synapses may affect neighboring GABAergic synapses, leading to an impairment of GABAergic function. In particular, in pathological conditions, zinc released from aberrantly sprouted mossy fibers may cause chronic changes in cell excitability and epileptic seizures (Buhl et al., 1996). Diffusion of zinc, caused by spill over, is expected to be much slower than the transient release of GABA during synaptic transmission. This implies that in the time scale of 
synaptic events, fluctuations in $\mathrm{Zn}^{2+}$ concentrations may be regarded as tonic ones. Thus, the effects of $\mathrm{Zn}^{2+}$ on synaptic currents would be similar to those observed in "pre-equilibration" experiments.

\section{REFERENCES}

Andjus PR, Stevic-Marinkovic Z, Cherubini E (1997) Immunoglobulins from motoneurone disease patients enhance glutamate release from rat hippocampal neurones in culture. J Physiol (Lond) 504:103-112.

Assaf SY, Chung SH (1984) Release of endogenous $\mathrm{Zn}^{++}$from brain tissue during activity. Nature 308:734-738.

Auger C, Marty A (2000) Quantal currents at single-site central synapses. J Physiol (Lond) 526:3-11.

Banks MI, Pearce RA (2000) Kinetic differences between synaptic and extrasynaptic $\mathrm{GABA}_{\mathrm{A}}$ receptors in CA1 pyramidal cells. J Neurosci 20:937-948.

Berger T, Schwarz C, Kraushaar U, Monyer H (1998) Dentate gyrus basket cell $\mathrm{GABA}_{\mathrm{A}}$ receptors are blocked by $\mathrm{Zn}^{++}$via changes of their desensitization kinetics: an in situ patch-clamp and single-cell PCR study. J Neurosci 18:2437-2448.

Buhl EH, Otis TS, Mody I (1996) Zinc-induced collapse of augmented inhibition by GABA in a temporal lobe epilepsy model. Science 271:369-373.

Celentano JJ, Gyenes M, Gibbs TT, Farb DH (1991) Negative modulation of the $\gamma$-aminobutyric acid response by extracellular zinc. Mol Pharmacol 40:766-773.

Clements JD, Lester RAJ, Tong G, Jahr CE, Westbrook GL (1992) The time course of glutamate in the synaptic cleft. Science 258:1498-1501.

DeFazio T, Hablitz JJ (1998) Zinc and zolpidem modulate mIPSCs in rat neocortical pyramidal neurons. J Neurophysiol 80:1670-1677.

Edwards FA, Konnerth A, Sakmann B (1990) Quantal analysis of inhibitory synaptic transmission in the dentate gyrus of rat hippocampal slices: a patch-clamp study. J Physiol (Lond) 430:213-249.

Frederickson CJ (1989) Neurobiology of zinc and zinc-containing neurons. Int Rev Neurobiol 31:145-238.

Galarreta M, Hestrin S (1997) Properties of GABAA receptors underlying inhibitory synaptic currents in neocortical pyramidal neurons. J Neurosci 17:7220-7227.

Gingrich KJ, Burkat PM (1998) $\mathrm{Zn}^{++}$inhibition of recombinant GABA receptors: an allosteric, state-dependent mechanism determined by the $\gamma$-subunit. J Physiol (Lond) 506:609-625.

Jonas P (1995) Fast application of agonists to isolated membrane patches. In Single-channel recording (Sakmann B, Neher E eds), pp.231-243. New York: Plenum.

Jones M, Westbrook GL (1995) Desensitized states prolong $\mathrm{GABA}_{\mathrm{A}}$ channel responses to brief agonist pulses. Neuron 15:181-191.

Jones MV, Westbrook GL (1997) Shaping of IPSCs by endogenous calcineurin activity. J Neurosci 17:7626-7633.
Jones MV, Sahara Y, Dzubay JA, Westbrook GL (1998) Defining affinity with the $\mathrm{GABA}_{\mathrm{A}}$ receptor. J Neurosci 18:8590-8604.

Kilic G, Moran O, Cherubini E (1993) Currents activated by GABA and their modulation by $\mathrm{Zn}^{2+}$ in cerebellar granule cells in culture. Eur J Neurosci 5:65-72.

Krishek BJ, Moss SJ, Smart TG (1998) Interaction of $\mathrm{H}^{+}$and $\mathrm{Zn}^{2+}$ on recombinant and native rat neuronal GABA $\mathrm{A}_{\mathrm{A}}$ receptors. J Physiol (Lond) 507:639-652.

Lee J, Cole TB, Palmiter RD, Koh J (2000) Accumulation of zinc in degenerating hippocampal neurons of ZnT3-null mice after seizures: evidence against synaptic vesicle origin. J Neurosci 20:RC791-795.

Legendre P, Westbrook GL (1991) Noncompetitive inhibition of $\gamma$-aminobutyric acid $_{\mathrm{A}}$ channels by $\mathrm{Zn}^{2+}$. Mol Pharmacol 39:267-274.

Mozrzymas JW, Barberis A, Michalak K, Cherubini E (1999) Chlorpromazine inhibits miniature GABAergic currents by reducing the binding and by increasing the unbinding rate of $\mathrm{GABA}_{\mathrm{A}}$ receptors. $\mathrm{J}$ Neurosci 19:2474-2488.

Perrais D, Ropert N (1999) Effect of zolpidem on miniature IPSCs and occupancy of postsynaptic $\mathrm{GABA}_{\mathrm{A}}$ receptors in central synapses. J Neurosci 15:578-588.

Peters S, Koh J, Choi DW (1987) Zinc selectively block the action of $N$-methyl-D-aspartate on cortical neurons. Science 236:589-593.

Rassendren FA, Lory P, Pin JP, Nargeot J (1990) Zinc has opposite effects on NMDA and non-NMDA receptors expressed in Xenopus oocytes. Neuron 4:733-740.

Slomianka L (1992) Neurons of origin of zinc-containing pathways and the distribution of zinc-containing boutons in the hippocampal region of the rat. Neuroscience 48:325-352.

Smart TG (1992) A novel modulatory binding site for zinc on the GABAA receptor complex in cultured rat neurones. J Physiol (Lond) 447:587-625.

Smart TG, Xie X, Krishek BJ (1994) Modulation of inhibitory and excitatory amino acid receptor ion channels by zinc. Prog Neurobiol 42:393-441.

Tia S, Wang JF, Kotchabhakdi N, Vicini S (1996) Developmental changes in cerebellar granule neurons: role of $\mathrm{GABA}_{\mathrm{A}}$ receptor $\alpha 6$ subunit. J Neurosci 16:3630-3640.

Timm F (1958) Zur histochemie des ammonshorngebietes. Z Zellforsch 48:548-555.

Vogt K, Mellor J, Tong G, Nicoll R (2000) The actions of synaptically released zinc at hippocampal mossy fiber synapses. Neuron 26:187-196.

Wenzel HJ, Cole TB, Born DE, Schwartzkroin PA, Palmiter RD (1997) Ultrastructural localization of zinc transporter-3 (ZnT-3) to synaptic vesicle membranes within mossy fiber boutons in the hippocampus of mouse and monkey. Proc Natl Acad Sci USA 94:12676-12681.

Westbrook GL, Mayer ML (1987) Micromolar concentrations of $\mathrm{Zn}^{2+}$ antagonize NMDA and GABA responses of hippocampal neurons. Nature 328:640-643. 